\title{
Some preliminary thoughts on epistemological transformation and the study of the Old Testament
}

\author{
Author: \\ S.D. (Fanie) Snyman ${ }^{1}$ \\ Affiliation: \\ ${ }^{1}$ Department of Old \\ Testament, University of the \\ Free State, South Africa \\ Correspondence to: \\ Fanie Snyman \\ Email: \\ snymansd@ufs.ac.za \\ Postal address: \\ PO Box 339, Bloemfontein \\ 9300, South Africa \\ Dates: \\ Received: 14 Sept. 2012 \\ Accepted: 18 Feb. 2013 \\ Published: 05 Sept. 2013 \\ How to cite this article: \\ Snyman, S.D., 2013, 'Some \\ preliminary thoughts \\ on epistemological \\ transformation and the \\ study of the Old Testament', \\ Verbum et Ecclesia 34(2), Art. \\ \#794, 5 pages. http://dx.doi. \\ org/10.4102/ve.v34i2.794

\section{Copyright:} \\ (c) 2013. The Authors. \\ Licensee: AOSIS \\ OpenJournals. This work \\ is licensed under the \\ Creative Commons \\ Attribution License.
}

Read online:
This contribution addressed the question of epistemological transformation in the study of the Old Testament in South Africa. Epistemological transformation entails the way in which we think of knowledge: what do we teach, why do we teach the knowledge that we teach and how do we teach? This contribution focused on the first and second aspects of knowledge. The aspect of transformation brings to mind the post-1994 situation in South Africa. In view of the major transition South Africa has made in terms of an inclusive democratic dispensation this new state of affairs, combined with the past we came from, necessitates a process of epistemological transformation in the study of the Old Testament. At the occasion of the retirement of a colleague it might be appropriate to look back and open up some possibilities for the future of Old Testament studies in South Africa.

\section{Introduction}

To think and rethink what we as Old Testament scholars do when teaching and researching the Old Testament within a South African context is a luxury we seldom allow ourselves. Pressures of schedules, publishing articles, writing books, preparing lectures, mentoring post-graduate students, reading papers, attending meetings and the ever present demon of administrative responsibilities prevent us from reviewing what we do in our profession.

This contribution addresses the question of epistemological transformation in the study of the Old Testament in South Africa. Epistemological transformation entails the way in which we think of knowledge: what do we teach, why do we teach the knowledge that we teach and how do we teach? This contribution focuses on the first and second aspects of knowledge. In this regard, Jansen (2012) made the following useful remark:

$[K]$ nowledge transformation is much more than corrective content; it is the baggage that comes with our understanding of knowledge, its ideological moorings and value propositions. Epistemological transformation is not the replacement of one set of knowledges (conservative) with another (liberal or radical). It is, in a university context, at the very least a treatment in curricular terms of the many different understandings of knowledge (in the broadest sense) in the disciplines of multi-disciplines being taught or researched. (p. 15)

The aspect of transformation brings to mind the post-1994 situation in South Africa. In view of the major transition South Africa has made in terms of an inclusive democratic dispensation this new state of affairs, combined with the past we came from, necessitates a process of epistemological transformation. This contribution operates with the presumption that 'such knowledge may open new insight in the human and cosmic condition, that it may contribute to social well-being' (Venter 2012:48). Knowledge is never neutral or innocent but entails concepts such as power, representation, responsibility and the service of the good life (Venter 2012:49-50). Having said this it means that the epistemological choices we make have ethical implications which must also be considered.

\section{A view from the past}

Thinking on the issue of epistemological transformation does not happen in a vacuum. The present time was preceded by a history. It should be kept in mind that the scientific study of the Old Testament is a fairly new undertaking in South Africa. The Old Testament Society of South Africa was founded a mere 55 years ago in 1957, making it the first theological society of its kind in South Africa (Le Roux 1993:11). Even as late as 1971 Old Testament studies in South Africa could be characterised as mainly conservative in approach, lacking critical scholarship (Le Roux 1993:26). Prior to the 1940s doctoral degrees in Old Testament were not conferred by South African universities (Le Roux 1988:160-180). Students interested in the Old Testament studied mainly at Dutch or German universities to obtain doctoral degrees. Over the years the guild of Old Testament scholarship kept a close link with especially the developments in the field of Old Testament studies in Europe. This was done by inviting European scholars to the 
annual meetings of the Old Testament Society of South Africa (OTSSA) (Th.C. Vriezen from Utrecht, G. Fohrer from Erlangen, J. Bright from Richmond, O. Kaiser from Marburg and R. Rendtorff from Heidelberg, to name a few examples). In this way South African Old Testament scholars by and large follow the lead provided by European and American scholarship. It is therefore no coincidence that books written by visiting scholars became prescribed works for both undergraduate and post-graduate students. This link with European colleagues paved the way for what may be called a first epistemological transformation from a predominantly conservative approach to the study of the Old Testament to critical scholarship. The negative result of this firm link with Europe and America was that the scientific debate(s) was dictated by European interests and that it was mainly a White (male) debate with little concern for a broader South African context (Deist 1994a:363).

In passing, we as South African Old Testament scholars also have to remind ourselves that we are not unique in thinking of and bringing about epistemological change in especially the field of Old Testament studies. Old Testament studies in Latin America went through a similar process (Carroll 1998:144-157). In a way a similar process can be detected in South Korea as well. Students from South Korea obtain post-graduate qualifications from universities elsewhere (USA, Europe, South Africa), take up teaching positions at universities and seminaries and then apply their insights gained to current Korean conditions.

The year 1994 stimulated a kind of second epistemological transformation in Old Testament studies. The late Prof. J.P.J. (Hannes) Olivier (University of Stellenbosch) initiated a special congress of Old Testament scholars to reflect on the way forward for the study of the Old Testament. Old Testament scholars sensed the need for taking stock of and rethinking the study of the Old Testament in South Africa after the political change to an inclusive democracy in 1994. The papers read at that congress were eventually published as a special edition of Old Testament essays. Three interesting features of that conference can be noted. Firstly, already in 1994 a remarkable diversity of approaches was advocated and followed (Botha et al. 1994; Deist 1994b:34-36). Papers were read on a variety of approaches followed in terms of a literary, historical and theological understanding of the Old Testament. Secondly, the emphasis in the papers read was more on taking stock of what was happening than envisioning new directions Old Testament scholarship may take in future. Thirdly, in terms of race and gender representation, only one (White) woman and two Black people read papers out of a total of 39 papers read. In fact, the White to Black ratio in terms of membership of the Old Testament Society of South Africa (OTSSA) was an astonishing 155 to 3 (Deist 1994b:42). Since 1994 this situation has changed: there was a dramatic increase in the membership of both women and Black people to the OTSSA and consequently it is no longer strange for women (either Black or White) and Black men to take part in the proceedings and to read papers at annual congresses of the OTSSA. During the most recent meeting of the OTSSA (June 2012) no less than 17 papers were read by Black participants compared to 25 by White participants.

The most obvious direction to take was to take cognisance of the African context of studying the Old Testament. This'turn to Africa' was especially emphasised by Deist (1994b:40-42), who challenged South African Old Testament scholars to start asking what questions are posed from our context and urged that 'we have to get the African discussion going'. This observation proves Venter's (2012) interpretation that:

[ $t$ ]he 1994 caesura is a real historical transition from one political dispensation to other; but is more than that: it is also a tensive symbol signifying two radically different social visions. The discourse on Apartheid as a totalizing ideology penetrating all spheres of live, from the sexual to the economic, employing all possible rhetorical legitimization, in particular the religious, will probably never reach closure. The legacy of injustice visibly and painfully scars the South African landscape; the more insidious tentacles are slowly emerging: how it has polluted identities, minds and scholarship. (p. 46)

\section{Considering the possibilities for epistemological transformation}

What should the face of Old Testament studies be in future? A bewildering array of possibilities confronts Old Testament scholars. One option is to go on doing'business as usual' with an exclusive focus on trends in the Euro-American (Western) environment. There is a growing tendency to standardise curricula to be compatible with institutions of higher education all over the world which inevitably will be to the detriment of the study of the Old Testament in Africa. At the same time there is the urge to 'turn to Africa'. Taking cognisance of research results and publications from Africa in terms of Old Testament scholarship is far more important now than a couple of years ago. The stance taken here is that one should not take an either/or approach but rather a both/ and approach. Due to the restraints of space not all areas of Old Testament study can be covered here. Whilst attention will be paid to biblical hermeneutics, the theology of the Old Testament, the ethics of the Old Testament, the exegesis and the history of Israel, regrettably no attention will be paid to other important areas such as socio-cultural, religionhistorical and archaeological aspects of Old Testament study. Whilst this contribution argues the theoretical need for epistemological transformation, little attention can be paid to the practical implications in terms of the various aspects of Old Testament study.

\section{Rethinking the curriculum for Old Testament study}

When rethinking the curriculum of Old Testament study at South African universities we should not take an either/or approach, meaning that we opt either for an African view on the Old Testament or for a Western view on the Old Testament. Nor should we think in terms of developing curricula suited for African students versus curricula for Western or White (African) students. We should rather 
broaden the curricula to include both perspectives. On the one hand it will be foolish to simply abandon the link with the Euro-American (Western) study of the Old Testament. On the other hand our context in Africa demands an even closer link with African Old Testament scholarship. The popular term 'glocal' may be an appropriate in this regard. The study of the Old Testament in South Africa should be both global and local, hence 'glocal'. Combining both an African and a Western perspective on the study of the Old Testament will enrich students' insight in the Old Testament and will equip them more adequately to use and apply the Old Testament in society and the practical ministry. This was also the way in which Old Testament studies had developed in Latin America. According to Carroll (1998:151) the challenge before the Latin American (evangelical) church is to continue developing its own Old Testament literature in order to complement First World studies. The issues to be addressed in a Latin American context are remarkably close to those in South Africa. Carroll (1998:151) highlights issues such as poverty, national reconstruction, the fate of refugees after the termination of civil war, the status and rights of women, racism and religious pluralism.

If one takes a bird's eye view of the tripartite division of the Old Testament and Hebrew Bible in the Torah, Prophets and Writings, one may make the following cursory suggestions. The law codes in the Pentateuch are to a large extent directed to provide guidelines for harmonious neighbourly love, making it possible for human beings to live together in relative peace. Living together as human beings in a country marked by diversity on so many levels of society is an ongoing challenge for South Africans. Both the Torah and the Prophets are to a large extent narrative material containing interesting stories of Israel's past. Africa too is known for its stories and in this way a fruitful interaction can take place in an interface between the stories told in the Old Testament and the stories told in African culture.

The phenomenon of prophesy forms a prominent part of the Old Testament whilst prophesy also occurs in African societies - African Old Testament scholars have discovered links between Old Testament prophesy and African prophesy. The emphasis of prophetic literature on issues of social justice may serve as an interesting meeting point where the claim for social justice in the Old Testament meets the lack of social justice in many current societies.

The same can be applied to wisdom literature. The Old Testament is rich in wisdom literature; African culture has a wealth of wisdom sayings that complement Old Testament wisdom in a remarkable way. By bringing the Old Testament closer to the African context and vice versa a renewed appreciation for the Old Testament can be fostered. In more practical terms one may think of the book of Job dealing with the question of unjust suffering and the way in which many people suffer unjustly (cf. Masenya 2001:186-199). The Song of Songs can be read to address the issue of sexual love in a time when people affected by HIV and AIDS are rampant in society.
If we take this route seriously, South Africa may become an exciting meeting ground where different emphases, methodologies and perspectives may come together. ${ }^{1}$ Broadening perspectives to include both African and Western perspectives can be taken even one step further to include also Asian perspectives on the Old Testament. Broadening our perspective in this way will not only enrich our understanding of the Old Testament but it will also show the relativity of interpretation.

One of the benefits of studying the Old Testament often taken for granted is that this study is an inter-faith and interreligious enterprise where religious or ecclesial confessions and doctrines play an insignificant role. The guild of Old Testament scholars are made up of Roman Catholics, Protestants, evangelicals, charismatics, Jews, agnostics, atheists et cetera.

\section{Biblical hermeneutics}

The fact that the Old Testament is still read and appreciated in church and society can be ascribed to the constant interpretation of the Scriptures. To read the Old Testament is to interpret the Old Testament. The Old Testament is in a process of continuing interpretation, appropriation and application to current situations. This process requires hermeneutical skills in order to arrive at legitimate and valid applications of texts from the Old Testament. To a certain extent one may even say that the quest for knowledge is a hermeneutical exercise in itself. The well-known distinction between knowledge as 'explanation' (erklären) and 'understanding' (verstehen) is still useful -'explanation' refers to the kind of knowledge generated in the natural sciences whilst 'understanding' is knowledge attained by the humanities or Geisteswissenschaften (Van Niekerk 2011:114115). African biblical hermeneutics is a broad term covering a variety of approaches (Du Toit 1998:377-380) but in itself it does not differ from this basic premise in hermeneutics. According to African biblical scholars hermeneutics comprises the art of interpreting a biblical text in order to understand its original meaning and then delineate its significance for the contemporary audience (Gatti \& Batsa 2011:167). The post-1994 political dispensation asks for a renewed thinking of what African biblical hermeneutics should look like in future. Contextualisation in terms of an inclusive democratic non-racial society demands innovative thinking.

The complaint is often voiced that Euro-American Old Testament scholarship tends to 'freeze' the message of the Old Testament in the historical context of the text. The other side of the coin is that all too often an inappropriate application of Old Testament texts is made, resulting in a fundamentalist interpretation of the Old Testament. If this observation is more or less correct, it points to a lack of hermeneutical skills in theological training. Old Testament scholarship in South Africa will render pastors, readers of

1.In a personal remark made to me during the June 2012 congress of the OTSSA an European Old Testament scholar indicated that this was the very reason he attends European Old Testament scholar indicated that this was the very reason he attends
congresses of the OTSSA in South Africa as this is the place where Euro-American congresses of the OTSSA in South Africa as this
and African Old Testament scholarship meet. 
the Old Testament and the church in general a tremendous service if the hermeneutical skills of future pastors, ministers and readers of the Old Testament can be enhanced. On the one hand we as Old Testament scholars will have to show the relevance of Old Testament texts to current situations by moving beyond the historical meaning of a text whilst on the other hand we will have to cultivate a hermeneutical sensitivity to curb the easy answers a fundamentalist interpretation of Old Testament texts sometimes offer. The field of biblical hermeneutics is a complex one in which there are many options and varieties of approaches to choose from (Conradie \& Jonker 2001; Maimela \& König 1998; Smit 2006). If we think of hermeneutics as the art of interpreting, understanding and appropriating Scripture in current times, we should pay more attention to this in teaching the Old Testament.

In fact, the quest for adequate hermeneutics is so important that serious consideration should be given to developing an independent module in biblical hermeneutics as part of the practical outcome of a process of epistemological transformation. If we may once again draw on a similar experience elsewhere in the world, a course on hermeneutics and contextualisation was offered at a seminary in Guatemala with great success (Carroll 1998:156).

\section{Contextualise the theology of the Old Testament}

Old Testament theologies bear the stamp of the particular context they emanate from. Is it pure coincidence that Eichrodt (1961) wrote his Old Testament theology with covenant as the central theme or is it also a reflection of his Calvinistic background? The Old Testament theology of Von Rad (1975) bears the mark of post-World War II Germany. Gerstenberger (2002:ix) admits that his rendering of Old Testament theology was influenced by his teaching Old Testament in Brazil and Germany. The theology of the Old Testament written by Brueggemann (1997) clearly reflects an American context. In fact, in an article Brueggemann (2012b:28) admits it overtly: 'My effort at OT theology needs to be understood in the context of U.S. scholarship and U.S. culture'.

There is a need for a (South African) contextualised grip on the theology of the Old Testament. On more than one occasion the lack of a proper theological engagement by South African Old Testament scholars has been mentioned. The assessment of Deist (1994b:37) is that Old Testament scholars are poor theologians, that doctoral dissertations on the Old Testament seldom reflect on the theological implications of the research results and that publications on Old Testament theology are lacking. Themes from the Old Testament should be incorporated into the curriculum to encourage students to think and to let them explore possibilities of relating the Old Testament and its theologies to their respective situations. Should we fail to do this it might be that our subject may become irrelevant to the South African context. My experience with students is that they are eager to take part in discussions on the contextual dimension of relevant themes from the theology of the Old Testament. Because the Old Testament itself is a contextual document directed to different communities in the course of history, it stands to reason that it should be contextualised anew whenever it is read in current communities.

This need for a contextualisation of the Old Testament is not unique to the African continent. The same need existed in Latin America. Carroll (1998:151) observes that 'our sociocultural world does influence the lenses with which we read the Old Testament ...'

\section{Contextualise the ethics of the Old Testament}

A neglected field of study in the curriculum of Old Testament studies is the field of ethics of the Old Testament (cf. Wright 2004). There is little need to argue the point that many South Africans find themselves in ethical disarray. The unacceptably high levels of crime, corruption, ethical misconduct, sporadic incidents of xenophobia and the rate of people infected by HIV and living with AIDS are but a few examples.

A renewed focus on the ethical values underlying the Old Testament can therefore equip leaders in church and society to provide at least a part of the South African community with ethical values relevant to the current situation. An ethical awareness can potentially change the way students think of society, individuals in society and the responsibilities one has as a member of society.

\section{Contextualise the exegesis and history of the Old Testament}

The dominant Western way of viewing the Old Testament is to locate the meaning of the text in history. This is part and parcel of the way the study of the text of the Old Testament has been handled in especially the Euro-American context. Once the meaning of the text in history has been located, the aim of exegesis has been fulfilled. Any attempt to contextualise the text for a current situation is viewed as going beyond what ought to be done and even as less academic. This is exactly the experience of Carroll (1998:153), who observed that students studying in First World institutions had learnt from early on from their teachers and thesis advisors that they should deal with the text only and not delve into contextual issues. West (2002:150-151) remarks in this regard that in many cases 'the trained South African biblical scholars have been trained in the academies of the west and that much of their reading continues to come from this site of biblical interpretation'. This kind of approach does not satisfy scholars, students or preachers in Africa. Adamo (2012) is quite vocal on this:

The old paradigm of historical critical exegesis in the 'First World' is becoming a problem in the light of African culture. To a certain extent, it has become an obstacle to African critical thinking in the light of African culture. This is because Western exegesis has subjected the Bible to abstract, individualized and neutralized reading, characterized by positivism, empiricism or radical detachment in the name of objectivity. (p. 10) 
There is a real and urgent need for a contextualisation of the historical meaning of Old Testament texts. The interpretation or exegesis of a text is finished only when the text speaks to a particular community.

The need for exegesis of the text of the Old Testament from an African perspective should be addressed. Western ways of exegesis do not meet the needs of African readers of the Old Testament. Indigenous authentic reading strategies need to be refined. The need to address the pressing needs of society should be combined with a well informed and methodologically sound engagement with the biblical text. It should also be made clear that a contextualisation of the Old Testament does not equal a devotional reading of texts.

The contextualisation of Old Testament texts into an African context is perhaps the hallmark of an African and South African interpretation of the Old Testament. Abasili's (2011:555-573) treatment of Tamar serves as a case in point. Methodologically Abasili (2011:556) opted for African feminist hermeneutics from the perspective of an Igbo (African) woman. Drawing extensively on both Western and African literature a careful and sensitive reading of Genesis 38 is given. At the end of the research the story of Tamar is contextualised within an African community: 'To African women in particular and women living in patriarchal society in general, Tamar is a model for courageous fight against injustice and male subjugation in such a society' (Abisili 2011:571).

The same can be applied to studying the history of Israel. We study the history of Israel for more than only knowing what happened historically in Old Testament times. The remarkable fact is that Africa was part of the scene of Old Testament times. Egypt is mentioned and the land of Kush is the Ethiopia of today. The relevance of the history of Israel must also be contextualised into a South African context. The search for the relevance of the history of Israel is not restricted to a South African context only. Brueggemann (2012a) relates the Babylonian exile of Judah to current America.

Old Testament scholars are often amazed at what is done with the Old Testament in terms of its interpretation and appropriation in local communities but at the same we have never equipped students with the critical apparatus for and knowledge of applying and contextualising the Old Testament.

\section{Conclusion}

When reading Western scholarly literature on the Old Testament it is interesting to note how Old Testament scholars from different countries dig into their own tradition of Old Testament scholarship in order to answer new problems. In South Africa we still lack a firm and longstanding tradition of Old Testament scholarship. It has often been said that we are still too dependent on the results and trends in Western Old Testament scholarship. By embarking on a process of truly bringing together African and Western Old Testament scholarship we can perhaps begin to create a South African tradition of scholarship for future generations of Old
Testament scholars and at the same time contribute to Old Testament scholarship in general. Perhaps we may give a new meaning to the maxim ex Africa semper aliquid novi [out of Africa always something new].

\section{Epilogue}

I dedicate this contribution to Prof. Jurie le Roux, who has a keen interest in the past as well as the future of Old Testament studies in South Africa. His tireless endeavours over many years to enhance Old Testament scholarship will be a lasting legacy to a future generation of Old Testament scholars.

\section{Acknowledgements Competing interests}

The author declares that he has no financial or personal relationship(s) which may have inappropriately influenced him in writing this article.

\section{References}

Abisili, A., 2011, 'Seeing Tamar through the prism of an African woman: A contextual reading of Genesis 38', Old Testament Essays 24(3), 555-573.

Adamo, D.T., 2012, 'Decolonizing Psalm 91 in an African perspective with special reference to the culture of the Yoruba people of Nigeria', Old Testament Essays 25(1), 9-26.

Botha, P.J., Bosman, H.L., Burden, J.J. \& Olivier J.J. (eds), 1994, 'Understanding the Old Testament in South Africa', Old Testament Essays 7(4), 63-202.

Brueggemann, W., 1997, Theology of the Old Testament: Testimony, dispute, advocacy, Fortress, Minneapolis.

Brueggemann, W., 2012a, Out of Babylon, Amazon.com, viewed March 2012, from http://www.amazon.com

Brueggemann, W., 2012b, 'Theology of the Old Testament: Testimony, dispute, advocacy revisited', Catholic Biblical Quarterly 74, 28-38.

Carroll, M.D., 1998, 'Perspectives on teaching the Old Testament from the Two-Thirds World', in H.S. Hess \& G.J. Wenham (eds.), Make the Old Testament live: From curriculum to classroom, pp. 144-157, Eerdmans, Grand Rapids, MI.

Conradie, E.M. \& Jonker, L.C., 2001, Angling for interpretation: A guide to understand the Bible better, University of the Western Cape, Bellville. (Study Guides in Religion and Theology 4)

Deist, F., 1994a, Ervaring, rede en metode in Skrifuitleg: 'n Wetenskapsteoretiese ondersoek na Skrifuitleg in die Nederduits Gereformeerde Kerk 1840-1990, RGN, Pretoria.

Deist, F., 1994b, 'South African Old Testament studies and the future', Old Testament Essays 7(4), 33-51.

Du Toit, C., 1998, 'African hermeneutics', in S. Maimela \& A. König (eds.), Initiation into theology: The rich variety of theology and hermeneutics, pp. 373-398, Van Schaik, Pretoria.

Eichrodt, W., 1961, Theology of the Old Testament, vol. I, SCM, London.

Gatti, N. \& Batsa, G.O., 2011, Journeying with the Old Testament, Peter Lang, Bern. (Das Alte Testament im Dialog Band 5)

Gerstenberger, E.S., 2002, Theologies of the Old Testament, Clark, Edinburgh.

Jansen, J., 2012, 'Can the theological leopard change its own spots? On the transformation of university knowledge', in R. Venter \& F. Tolmie (eds), Transforming theological knowledge-Essays on theology and the university after Transforming theological knowledge-Essays on the
apartheid, pp. 9-20, SUN Media, Bloemfontein.

Le Roux, J.H., 1988, 'Die Departement Ou Testament, 'n halwe eeu oud', Skrif en Kerk $9(2), 160-180$.

Le Roux, J.H., 1993, A story of two ways: Thirty years of Old Testament scholarship in South Africa, Verba Vitae, Pretoria.

Maimela, S. \& König, A. (eds.), 1998, 'Initiation into theology: The rich variety of theology and hermeneutics', Van Schaik, Pretoria.

Masenya, M.J., 2001, 'Between unjust suffering and the "silent" God: Job and HIV/ AIDS sufferers in South Africa', Missionalia 29, 186-199.

Smit, D., 2006, Neem, lees! Hoe ons die Bybel hoor en verstaan, Lux Verbi, Wellington.

Van Niekerk, A.A., 2011, 'Understanding theology as understanding', Acta Theologica, suppl. 14.

Venter, R., 2012, 'Theology, the post-apartheid university and epistemological transformation: Intimating the shape of the challenge', in R. Venter \& F. Tolmie (eds.). Transforming theological knowledge - Essays on theology and the university after apartheid, pp. 45-72, SUN Media, Bloemfontein. PMid:22485002

Von Rad, G., 1975, Old Testament theology, vol. I, SCM, London.

West, G.O., 2002, 'Indigenous exegesis: Exploring the interface between missionary methods and the rhetorical rhythms of Africa: Locating local reading resources in the academy', Neotestamentica 36, 147-162.

Wright, C.J.H., 2004, Old Testament ethics for the people of God, Inter Varsity Press, Leicester. 